\title{
Commonwealth Local Government Forum's support of Local Councils Associations in Pakistan
}

\section{Commonwealth Journal of Local Governance \\ Issue 21: December 2018}

http://epress.lib.uts.edu.au/ojs/index.php/cjlg

\author{
Noor Akbar \\ Commonwealth Local Government Forum \\ 55-58 Pall Mall \\ London \\ SW1Y 5JH \\ UK
}

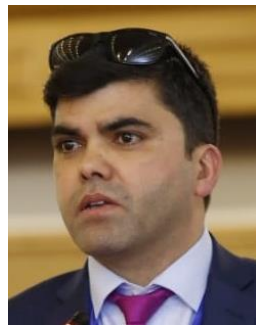

Email: noor.akbar@clgf.org.uk

\begin{abstract}
After a brief overview of the recent developments in the legal framework for local government in Pakistan, this paper summarises the objectives and activities to date of the Commonwealth Local Government Forum's project 'Strengthening the Associations of Local Governments and their Members for Enhanced Governance and Effective Development Outcomes in Pakistan'. The project seeks to strengthen local democracy and good governance through the local councils associations in the four provinces of Pakistan: Baluchistan, Punjab, Sindh and Khyber Pakhtunkhwa. The project seeks to support local government to deal with the unique challenges of inclusive representation and equitable and effective service delivery. Building on the recently promulgated provincial local government acts, the project aims to strengthen the capacity of the local councils associations to raise the voice of local government and ensure they are able to play their appointed developmental role at the local level. The project's main aims are to strengthen how the local councils associations actively provide services to their members and advocate for the betterment of local government in Pakistan and pilot the territorial approach to local development so as to align the general methodology to the Pakistan context.
\end{abstract}

\section{Introduction}

In the past decade since the adoption of the $18^{\text {th }}$ Amendment to the Constitution, there have been significant developments in the legal framework governing local democracy in Pakistan. After a brief overview of these legislative developments for local government in each of Pakistan's four provinces, this paper summarises the objectives and activities to date of the Commonwealth Local Government Forum (CLGF)'s EU-funded project 'Strengthening the Associations of Local Governments and their Members for Enhanced Governance and Effective Development Outcomes in Pakistan'. The paper highlights how the project has sought to address the significant challenges faced in each province and to build on cross-provincial lessons for local government in the country.

DOI: https://doi.org/10.5130/cjlg.v0i21.6727

Article History: Received 26/03/19; Accepted 09/08/19; Published 20/09/19

Citation: Commonwealth Journal of Local Governance 2018, 21: 6727, https://doi.org/10.5130/cjlg.v0i21.6727

(C) 2019 Noor Akbar. This is an Open Access article distributed under the terms of the Creative Commons Attribution 4.0 Unported (CC BY 4.0) License (https://creativecommons.org/licenses/by/4.0/), allowing third parties to copy and redistribute the material in any medium or format and to remix, transform, and build upon the material for any purpose, even commercially, provided the original work is properly cited and states its license. 


\section{Local government in Pakistan}

Under Article 32 of the Constitution of Pakistan, it is the state's responsibility "to encourage local government institutions composed of elected local representatives and to provide special representation for peasants, workers and women" (Government of Pakistan 2012). The 18th Amendment to the Constitution, adopted in 2010, requires provinces to pass legislation establishing local government systems and devolve political, administrative and financial responsibility and authority to the elected local representatives. Following a constitutional petition in Baluchistan in April 2012, the Supreme Court of Pakistan (2013) directed the provinces to establish local government systems as mandated by the Constitution in order to address the socio-political issues of the people. A sustained advocacy campaign from the provincial local government associations and wider civil society along with significant pressure from the Supreme Court of Pakistan resulted in the four provinces adopting local government legal frameworks (CLGF 2014a; VNG 2015).

The Baluchistan provincial government was the first to dissolve its previous system of local government in January 2010, and although the Baluchistan Local Government Act 2010 was passed the same year local government elections were not held in the province until late 2013 (CLGF 2014b). Sindh and Punjab provinces followed and both passed their respective new local government acts in 2013. Sindh and Baluchistan provinces chose to follow the framework of the Local Government Ordinance 2001 (e.g. Government of Sindh 2002) with only minor changes, whereas the Punjab province opted to follow the 1979 local government system (Kakar 2016). In the Khyber Pakhtunkhwa (KPK) Local Government Act, 2013 (Government of Khyber Pakhtunkhwa 2013) however, significant changes were made to establish a broad-based local government system from district to village level. The KP provincial government allocated $30 \%$ of the provincial development budget to the local governments to provide basic services in a more effective manner.

\section{Local councils associations (LCAs) in Pakistan}

An association of local authorities provides a voice for and services to its members with a view to advancing political and fiscal devolution. The Local Councils Association of Punjab (LCAP) was the first to be established in in the country in 2006 (VNG 2015) which set the stage for local governments in other provinces to establish their own associations, with the Local Councils Association of Baluchistan (LCAB) forming in 2008 followed by the Local Councils Association of Khyber Pakhtunkhwa (LCAKP) in 2009 and the Local Councils Association of Sindh (LCAS) in 2010. 
These associations were established with the objectives to:

- Increase the voice and effective participation of councillors and citizens in local government planning, development and decision-making within the framework of participatory governance.

- Strengthen functioning and capacity of local governments and facilitate cooperation among all tiers of local governments, to encourage and facilitate the resolve of common issues.

- Establish and maintain good relations with upper governments for shared interests.

- Provide a united and influential voice in the representation of local governments' interests on policies, legislation, plans and development programmes and other measures affecting them and to provide forum and other mechanisms to share knowledge and best practices at local, national and international levels (LCAP 2019).

\section{European Union and support for local authorities}

In May 2013, the European Union (EU) issued a Communication on local authorities that emphasised empowering local authorities in partner countries for enhanced governance and more effective development outcomes (European Union 2015a). This Communication integrates the results of the Structured Dialogue on the involvement of Civil Society Organisations and Local Authorities in EU development cooperation, the EU's renewed approach to poverty reduction and sustainable development defined by the Communication Increasing the Impact of the Development Policy: an Agenda for Change and related Communications and Council Conclusions, as well as the results of the stakeholder consultation carried out on the basis of the Issue Paper Local Authorities in Development (European Union 2013). Furthermore, the Communication takes into account the international aid and development effectiveness agenda, as lastly shaped by the Busan outcome document, especially paragraph $21^{1}$ (OECD 2011, see also Platforma 2011).

This Communication recognised local government as an actor in development, allowing the EU to specifically target development funds to local government and its associations. A budget line for local authorities and civil society organisations made funding available to local government to support key development priorities at the local level and strengthen decentralisation and subsidiarity at the regional, national and sub-national levels (paragraph 21). In parallel and following significant advocacy from the main international local government organisations, the EU in 2015 signed a set of five Framework Partnership Agreements, one of which was with CLGF. This political agreement outlined the main areas where these organisations and the EU shared key priorities and recognised the monopoly position of these organisations to represent local government.

\footnotetext{
1 "Parliaments and local governments play critical roles in linking citizens with government, and in ensuring broad-based and democratic ownership of countries' development agendas. To facilitate their contribution, we will: $b$. Further support local governments to enable them to assume more fully their roles above and beyond service delivery, enhancing participation and accountability at the sub-national levels" Busan Partnership for Effective Development Co-Operation, paragraph 21.
} 


\section{Project rationale}

In 2016 CLGF, LCAP and the EU delegation to Pakistan entered into discussions to design a project of support for the nascent local councils associations of the four provinces of Pakistan. The project titled 'Strengthening the Associations of Local Governments and their Members for Enhanced Governance and Effective Development Outcomes in Pakistan' responds to the global objectives, to enhance local authorities' contributions to governance and development processes, as mentioned in the EU's MultiAnnual Action Programme (MAAP) 2015-2017 for the 'Civil Society Organisations and Local Authorities' thematic programme (European Union 2015b). Of particular note is objective 2: To strengthen Pakistani local governments enabling them to effectively perform their roles as actors of local governance and development through a territorial multi-stakeholder approach. The programme will build the capacity of LCAs at the provincial and national level to support the local governments of Pakistan through advocacy, capacity building and training, exchange of good practice, and peer-to-peer support to promote and strengthen local governments' contribution to good governance and development. The project runs 2017-20 and is working both with the local councils associations in Sindh, Baluchistan, Punjab and KP to build their capacity, as well as with a set of pilot local councils in integrating the territorial approach to local development (TALD) into their planning processes (CLGF 2017).

Through building the institutional and operational capacities of national and provincial level institutions, the action will ensure long-term sustainability of outcomes, and enable the LCAs to respond to the needs of their members and continue to undertake both advocacy and service provision following the end of the action. The project is working to strengthen recognised and responsive institutions, which are genuinely representative and support them to build the requisite skills to position themselves as logical partners to enable local governments in Pakistan to effectively engage with government ministries, line departments, partner organisations and development bodies involved in local development in the long term. The project builds on CLGF's long-standing relationship with the four provincial LCAs and more recently the Association for Development of Local Governance (ADLG) the national association of local councils (CLGF 2016).

The project further works on strengthening the LCAs to engage in intergovernmental dialogue; and by building the advocacy capacity of the LCAs to bring issues and challenges being faced at the local level to provincial and national dialogue. The programme hopes to influence reform and ensure a local government voice in the revision of legislative and operational frameworks towards more participatory, accountable, responsive and integrated development planning, budgeting, and implementation processes at local, sub-national, and national levels. The programme aims to network CLGF's programme with others active in the sector and to work with the LCAs and ADLG to ensure that the associations and members are aware of initiatives underway and are encouraged to play a full role as partners where appropriate. There is significant scope for the LCAs to raise their profile as learning organisations and demonstrate their potential to donors as partners, not just in project planning and delivery, but also in disseminating lessons and results. 


\section{Project activities}

The project has recently entered its third year of operations and the second year of the project has focused on consolidating the institutional strengthening and restructuring of the three provincial local councils associations and ADLG. Following a successful first year of the project during which it put in place the foundations, year two built on this and saw the regularisation of the work of the LCAs. Strategic plans and advocacy work were developed and owned by the members of the LCAs, as well as the establishment of membership fee structures and collection of dues as part of the LCAs' work towards long-term sustainability. All four provincial LCAs have a functioning executive committee and president and elections for the new political leadership took place in LCAP, LCAS and LCAB. The political leadership works closely with the coordinators to drive the work of the LCAs. Also, the election for the president and vice presidents of the ADLG was completed.

Further, work is underway to pilot the TALD process at the council level (Rodriguez Bilbao 2015). Criteria for selection of councils has been agreed and ten pilot councils have been selected. The LCA coordinators, project staff as well as elected leaders from the pilot councils have undergone initial training and briefings and have started to implement TALD in their local communities. To kick-start the TALD pilot projects in districts Peshawar, Mardan and Malakand of Khyber Pakhtunkhwa province, CLGF organised TALD training for the members of these districts and supported processes of local consultation in each district in July 2019 (CLGF 2019b). In each district a diverse group of around 55 persons, including local government members, line departments, local businesspersons, members of civil society organisation (CSOs) and community stakeholders took part in the training session. The realisation of the pilot projects will start very soon following the TALD framework. The district nazims (mayor) of the three selected districts took keen interest in using the TALD framework in the pilot projects and their coming development projects as well. Now that local government politicians have worked with CLGF to lead these processes of local consultation, each council will develop a small implementation project to demonstrate the real outcomes of the TALD process to local communities. This project implementation will be supported by the CLGF project team and the Provincial Local Councils Association.

At the end of the second year of the programme, the LCAs are now in a much stronger position. They have increased their visibility and contributed in a more coordinated national/provincial policy dialogue on relevant issues, such as service delivery to their communities and improving access to local development finance (CLGF 2019a). The LCAs have received informal recognition from different departments and ministries and now have cordial professional relationships with provincial local government ministries in all four provinces. One example of such a partnership is the signing of a memorandum of understanding between LCAP and Ministry of Population Welfare, Punjab to help disseminate the ministry's messages at the grassroots level as a direct result of the LCA's advocacy of the role of local government in the province. In addition to reinforcing the core role and functions of 
the LCAs, year three of the project focusing on consolidating and expanding the work of the LCAs to ensure that they continue to represent and provide services to meet the needs of their members. It will see the associations enhancing their advocacy role, complete the TALD pilots and ensure that the results are assessed and disseminated. There will also be further opportunities for provincial and national meetings to strengthen the networks and to continue to increase the visibility of the LCAs and the role of local government as actors in development in Pakistan.

Visibility of LCAs has been increased in all provinces through holding district and union council level meetings by forming of district executive committees and restructuring of LCAs. LCA presidents and executives have been active in engaging with ministries responsible for local government (on both a political and administrative level). Following the national elections in July 2018, an interprovincial committee of the four provincial ministers has been formed to advance local government reforms. LCAKP, LCAP and LCAB held meetings with ministers and secretaries of local government regarding the government's plan to make changes in the local government system. LCAP has been invited to be part of this committee and has been taking part in coordination meetings and dialogues. Similarly, websites, Facebook pages and twitter accounts are active for each of the LCAs and are regularly updated. The content is province-specific and reflects the needs and priorities of local government in each province. Facebook is an especially useful and important platform used to update members and other interested parties on key meetings and policy advances with provincial government and other important partners.

At an interim project, assessment workshop was held in November 2018 to take stock of project progress to date; upcoming activity plans were shared and cross-provincial priorities and synergies identified. Participants further discussed how to maximise political impact, draw in new partners and increase the project's visibility. One activity to come out of the workshop was a plan for a national conference, which was held in January 2019 and brought together 500 members from the four associations with other key stakeholders, including provincial and federal government representatives, civil society and development partners. Additionally, in March 2019, an EU-sponsored independent result-oriented monitoring mission was held, which gave a very positive report of the project's relevance, efficiency, effectiveness and sustainability.

\section{Lessons learnt/challenges}

The 2018 general elections in Pakistan which saw a change in government inevitably had an impact on the timing of activities and particularly delayed the election of the LCA executive committees since many of the elected local government representatives were involved in their respective party's election campaigning. Whilst this led to the slow progression of other project activities, these are getting back on track now that the LCA executive committees are in place. 


\section{Conclusion}

This paper has highlighted in summary the approach as activities of the CLGF-EU 'Strengthening the Associations of Local Governments and their Members for Enhanced Governance and Effective Development Outcomes in Pakistan' project to strengthen local democracy and good governance through the LCAs in the four provinces. To date the project has seen significant advances in the institutionalisation of four provincial LCAs both through the securing institutional capacity through the appointment of full-time staff, office space and equipment, as well as significantly, the development of strategic plans laying out the key priorities for action with regard to advocacy, communication and member services. Working on the territorial approach to local development (TALD) has also provided the LCAs with a methodology for connecting local councils with citizens and stakeholders to discuss and agree development priorities in the local area. The piloting of TALD in ten councils in the next phase of the project will provide the LCAs with concrete experience in citizen outreach at the local level to be fed into both advocacy and member services. The hope is that as a result of the project the LCAs will have embedded capacity and will be in a position to provide a full range of services to their member local governments for the foreseeable future.

\section{Declaration of conflicting interest}

The author declared no potential conflicts of interest with respect to the research, authorship, and/or publication of this article.

\section{Funding}

The author is an employee of the Commonwealth Local Government Forum and works on the project outlined in this article funded by the European Union delegation to Pakistan.

\section{References}

CLGF. (2014a) Pakistan LGAs learn about leadership and advocacy. Available at: www.clgf.org.uk/whats-new/news/pakistan-lgas-learn-about-leadership-and-advocacy

CLGF. (2014b) Building advocacy capacity of local government in Pakistan. Available at: www.clgf.org.uk/whats-new/news/building-advocacy-capacity-of-local-government-in-pakistan

CLGF. (2016) CLGF supports launch of the first national local government association in Pakistan. Available at: www.clgf.org.uk/whats-new/news/clgf-supports-launch-of-the-first-national-local-governmentassociation-in-pakistan

CLGF. (2017) Workshop plans priorities to strengthen LGAs in Pakistan. Available at: www.clgf.org.uk/whats-new/news/workshop-plans-priorities-to-strengthen-lgas-in-pakistan

CLGF. (2019a) Pakistan local government: a partner in national development. Available at: www.clgf.org.uk/whats-new/news/pakistan-local-government-a-partner-in-national-development

CLGF. (2019b) Pakistan local government adopting a territorial approach. Available at: www.clgf.org.uk/whats-new/news/pakistan-local-government-adopting-a-territorial-approach

European Union. (2013) Local authorities in development. Issue Paper. Available at: http://eeas.europa.eu/archives/delegations/sri_lanka/documents/eu_sri_lanka/issue_paper_com_local_aut horities_en_(3).pdf [Accessed 27 July 2019]. 
European Union. (2015a) Empowering local authorities in partner countries for enhanced governance and more effective development outcomes. Available at:

https://ec.europa.eu/europeaid/sites/devco/files/communication-local-authorities-in-partner-countriescom2013280-20130515_en_4.pdf [Accessed 27 July 2019].

European Union. (2015b) Commission decision on the multi-annual action programme 2015-2017 'civil society organisations and local authorities'. Available at: https://ec.europa.eu/europeaid/commission-decisionmulti-annual-action-programme-2015-2017-civil-society-organisations-and-local_en

Government of Baluchistan. (2013) Baluchistan Local Government Act, 2010. Pakistan.

Government of Khyber Pakhtunkhwa. (2013) Khyber Pakhtunkhwa Local Government Act, 2013. Available at: http://lgkp.gov.pk/wp-content/uploads/2014/03/1.-A-printable-version-of-the-Khber-PakhtunkhwaLocal-Government-Act-2013.pdf

Government of Khyber Pakhtunkhwa. (2019) Khyber Pakhtunkhwa Local Government Amendment Act, 2019. Available at: http://lgkp.gov.pk/wp-content/uploads/2019/06/The-KP-Local-Government-AmendmenAct-2019.pdf

Government of Pakistan. (2012) The Consitution of the Islamic Republic of Pakistan. [As modified up until the $28^{\text {th }}$ Febrary 2012] Available at: www.na.gov.pk/uploads/documents/1333523681_951.pdf [Accessed 8 July 2018].

Government of Punjab. (2013) Punjab Local Government Act, 2013. Pakistan.

Government of Sindh. (2002) Local Government Ordinance 2001. Available at: https://sindh.gov.pk/dpt/services/RULES/SLGO\%202001\%20_February03_.pdf [Accessed 27 July 2019].

Government of Sindh. (2013) Sindh Local Government Act, 2013. Available at: www.pas.gov.pk/uploads/acts/Sindh\%20Act\%20No.XLII\%20of\%202013.pdf [Accessed 27 July 2019].

Kakar, A. (2016) Local government and Pakistan's reluctant political elite. Available at: http://eprints.lse.ac.uk/74551/1/blogs.lse.ac.uk-Local government and Pakistan's reluctant political elite.pdf [Accessed 14 June 2019].

Local Councils Association of the Punjab. (LCAP). (2019) Mission \& objective. Available at: www.lcap.org.pk/page.php?id=56 [Accessed 14 June 2019].

OECD. (2011) Busan partnership for effective development co-operation. Available at: www.oecd.org/dac/effectiveness/49650173.pdf [Accessed 20 July 2019].

Platforma. (2011) Development effectiveness at the local and regional level. Fostering synergies between local and regional governments and the EU in the post-Busan era. Available at: https://platforma-dev.eu/wpcontent/uploads/2017/03/Platforma-2013-Development-effectiveness-at-local-regional-level.pdf [Accessed 26 July2019].

Rodriguez Bilbao, J. (2015) What is the territorial approach to local development? Available at: https://europa.eu/capacity4dev/article/what-territorial-approach-local-development [Accessed 20 July 2019].

Supreme Court of Pakistan. (2013) Civil miscellaneous application No.6882/13 in Constitution petition No.77 of 2010. Available at: http://supremecourt.gov.pk/web/user_files/File/cma.6882-13.pdf [Accessed 27 July 2019].

VNG. (2015) Strengthening local governance and decentralization. Available at: www.vng-international.n1/wpcontent/uploads/2015/06/Strengthening_Local_Governance_and_Decentralization_En.pdf [Accessed 1 July 2018]. 